\title{
MARKET RESPONSE TO STOCK SPLITS IN THE NATIONAL STOCK EXCHANGE
}

\begin{tabular}{|l|l|}
\hline Babitha Rohit & Dr. Prakash Pinto \\
Assistant Professor, & Professor and Dean, \\
Department of Business Administration, & Department of Business Administration, \\
St. Joseph Engineering College, Vamanjoor, & St. Joseph Engineering College, Vamanjoor, \\
Mangalore 575 028. & Mangalore - 575 028. \\
Email - babitha.rk2002@gmail.com & Email - prakashpinto74@ gmail.com \\
\hline
\end{tabular}

\begin{abstract}
The Efficient Market Hypothesis is one of the most significant theories in standard finance. Market efficiency studies assess how rapidly and correctly the market reacts to a particular type of new information. Information usefulness studies assess the degree to which company returns react to release of a particular bit of news. In this direction the present study examines the Efficient Market Hypothesis in the Indian stock market. The effects of Stock splits announcements are studied for companies listed in the National Stock Exchange for the period 2009 to 2013. Event study methodology has been used to test the semi strong form of EMH. The study observes that average abnormal return on the day of announcement for the sample is $2.02 \%$ which is significant at $5 \%$ level.
\end{abstract}

Keywords: Efficient Market Hypothesis, Event Study, Stock splits, Average Abnormal Returns

\section{Market Response to Stock Splits in the National Stock Exchange}

\section{Introduction}

A market in which prices always 'fully reflect' available information is called 'efficient'. It is common to distinguish among three versions of the Efficient Market Hypothesis (EMH): the weak, the semistrong, and the strong forms of the hypothesis. The weak-form EMH asserts that stock prices already reflect all information that can be derived by examining market trading data such as the record of past prices, trading volume, or short interest. This account of the hypothesis implies that trend analysis is fruitless. The semistrong-form EMH states that all publicly available information regarding the prospects of a firm must be already reflected in the stock price. Such information includes, in addition to past prices, primary data on the firm's product line, quality of management, balance sheet composition, patents held, earnings forecasts, accounting practices, and so forth. Finally, the strongform EMH states that stock prices reflect all information relevant to the firm, even including information accessible only to company insiders, this account of the hypothesis is quite intense.

A stock split is one such corporate event that comes under the purview of semistrong form of efficient market hypothesis. A stock split is a decision by the company's board of directors, to increase the number of shares outstanding by issuing more shares to current shareholders. A stock split increases the number of shares in a public company. Each old share is split into a number of new shares with a decreased par value, leaving the total share capital untouched. By stock split, every stock holder gets additional 
stock without paying to the issuer company. The balance sheet items remain the same; except that the total number of outstanding shares of the company increases proportionately to the ratio of split. As per Efficient Market Hypothesis, stock split should not show any abnormal return on or during either announcement date or execution date. However there are large number of evidences available in US and European markets which shows that stock splits leads to abnormal positive return on and around announcement date (Fama et al, 1969; Lakonishok and Lev, 1987; McNichols and Dravid, 1990; Maloney and Mulherin, 1992; Ikenberry et al, 1996).

Fama et al (1969) defined a stock split as an exchange of shares in which at least five shares were distributed for every four formerly outstanding shares. Splits can occur in any ratio; the most commonly used ones being 2:1, 3:2, 5:4, 4:3 and so forth. In theory, a stock split is mainly an accounting change, which leaves investors no better or worse off than they were before the split (Denis and Strickland, 1998). However, there must be some benefits that arise from the split

\section{Literature review:}

Fama, Fisher, Jensen and Roll in 1969 examined 940 stock splits over the period 1927-1959. Using a market model and monthly returns they find on average an abnormal excess return of $34.07 \%$ over the 29 months preceding the split date for splitting companies. Grinblatt et al, (1984) show that stock split announcements are associated with excess positive returns following the announcement. The authors use a mean-adjusted returns methodology, developed by Masulis, in order to measure the excess returns. Lakonishok and Lev (1987) define split events around announcement dates using a sample size of 1015 in the time frame from 1963 to 1982. They also found significant abnormal returns for splitting firms preceding the splits (on average they find 53\% excess returns in aggregate during the 5 years preceding the split announcement). Providing further proof to the above studies Asquith et al. (1989) found statistically significant market adjusted excess returns of $56.8 \%$ for splitting firms for the 240 day time period preceding a split in the 19701980 time period. These studies confirm without a doubt that split events are preceded by very strong performances for the splitting companies as they compare to non-splitting firms. Lamourex and Poon (1987) find a statistically significant average excess return of $0.56 \%$ on the split ex-date. Ikenberry et al, (1996) also find market adjusted abnormal returns of about $3.38 \%$ around split announcements. Pilotte and Manuel (1996) report that the stock price response to a split varies with earnings realizations observed after previous splits. This suggests that the information content of a split their shares very infrequently compared to firms that are repeat splitters.

\section{Objectives}

1. To investigate the short-term behavior of stock prices around the stock split 
announcement date using data from the National Stock Exchange.

2. To measure returns around the split date to observe if it generates positive or negative abnormal returns.

3. To test the significance of the returns around the announcement date.

\section{Need for study}

The purpose of the present study is to identify the abnormal returns on the day of stock split announcement of companies which are listed on National Stock Exchange for the period 2009-2013. It analyses the pre and post effects of stock split announcement.

\section{Methodology}

The current study analyses the stock splits issue announcement dates of Indian publicly listed companies in the BSE for the period January 2009 to December 2013. The sources of secondary data are journal articles, company annual reports and websites of NSE and Moneycontrol.

The initial sample consisted of 110 companies listed on NSE that made stock splits issue from January 2009 to December 2013. Companies that had announced dividend, right issue or bonus shares during the time of event window and companies whose data were not available were not taken for the sample under the study. The final sample consisted of 56 companies listed on the National Stock Exchange.

The study follows the event study methodology by using the market model. The date of stock split announcement is ' 0 ' day. Estimation window for the study is $\mathrm{t}=$ -21 days to $t=-121$ days. The estimation window is used to determine the parameters $\alpha$ and $\beta$ of the market model. Event window is -20 days to +20 days. Pre split announcement window is -20 day to -1 day and post split announcement window is +1 day to +20 day. Expected Returns for individual securities are calculated using the market model. The CNX 500 is taken as the proxy for market index.

The daily returns are calculated for both the individual securities as well as market index using the following equation

$$
\mathrm{R}_{\mathrm{j}, \mathrm{t}}=\frac{\mathrm{P}_{\mathrm{t}}-\mathrm{P}_{\mathrm{t}-1}}{\mathrm{P}_{\mathrm{t}-1}} \times 100
$$

$\ldots 1$

Where, $R_{j, t}=$ Returns on security $j$ on time $t$ $P_{t}=$ Price of the security at time $t$ $\mathrm{P}_{\mathrm{t}-1}=$ Price of the security at time $\mathrm{t}-$

1

Returns for the event window are computed using the following market model equation

$$
\mathrm{R}_{\mathrm{j}, \mathrm{t}}=\alpha_{\mathrm{j}}+\beta_{\mathrm{j}} \mathrm{R}_{\mathrm{m}}+\mathrm{e}_{\mathrm{t}}
$$

$\ldots 2$

Where, $R_{j, t}=$ The daily return on security $j$ on time $\mathrm{t}$

$\mathrm{R}_{\mathrm{m}}=$ The daily return on the Indian stock market at day $\mathrm{t}$

$\alpha_{j}$ and $\beta_{j}=$ OLS intercept and slope coefficient estimators respectively

$$
e_{t}=\text { The error term for security } j \text { at }
$$
day $\mathrm{t}$

The expected return for the security $\mathrm{j}$ at day $\mathrm{t}$ is defined as $\mathrm{ER}_{\mathrm{j}, \mathrm{t}}=\alpha_{\mathrm{j}}+\beta_{\mathrm{j}} \mathrm{R}_{\mathrm{m}}$ 
Where, $\alpha_{j}, \beta_{j}$ are OLS estimators

The daily abnormal return is calculated as

$$
A R_{j, t}=R_{j, t}-E R_{j, t}
$$

Where, $\mathrm{AR}_{\mathrm{j}, \mathrm{t}}=$ Abnormal Returns on security $\mathrm{j}$ at time $\mathrm{t}$

$$
\mathrm{R}_{\mathrm{j}, \mathrm{t}} \quad=\text { Actual Returns on security } \mathrm{j}
$$

at time $\mathrm{t}$

$$
\mathrm{ER}_{\mathrm{j}, \mathrm{t}}=\text { Expected Returns on security }
$$

$\mathrm{j}$ at time $\mathrm{t}$

The Average Abnormal Return (AAR) is determined by the equation given below

$$
\mathrm{AAR}_{\mathrm{t}}=\frac{1}{\mathrm{n}} \sum_{\mathrm{t}=1}^{\mathrm{n}} \mathrm{AR}_{\mathrm{j}, \mathrm{t}}
$$

...5

Where, $\mathrm{AAR}_{\mathrm{t}}=$ Average Abnormal Returns on day $t$

$$
\mathrm{AR}_{\mathrm{j}, \mathrm{t}}=\text { Abnormal Returns on }
$$

security $\mathrm{j}$ at time $\mathrm{t}$

$\mathrm{n} \quad=$ Number of Sample

announcements

The Cumulative Average Abnormal Returns (CAAR) is calculated as follows $\mathrm{CAAR}_{\mathrm{k}}=\sum_{\mathrm{t}=1}^{\mathrm{k}} \mathrm{AAR}_{\mathrm{t}}$

...6

Where, $\mathrm{CAAR}_{\mathrm{k}}=$ Cumulative Average Abnormal Returns for the $\mathrm{k}^{\text {th }}$ period

$$
\mathrm{AAR}_{\mathrm{t}}=\text { Average Abnormal }
$$

Returns on time $\mathrm{t}$

The study uses cross sectional $t$ tests to examine the statistical significance of the AAR for each trading day. The cross sectional $\mathrm{t}$ test assumes that the day ' 0 ' abnormal returns are independent and identically distributed. The statistical significance is computed as follows:

$$
\begin{aligned}
& \mathrm{t}=\frac{\text { Mean Abnormal Return }}{\text { Standard Deviation }} \\
& \mathrm{t}(\mathrm{AAR})=\frac{\mathrm{AAR}_{\mathrm{t}}}{{\mathrm{S}\left(\mathrm{ARR}_{\mathrm{e}}\right)}}
\end{aligned}
$$

...7

Where $\mathrm{AAR}_{\mathrm{e}}$ is $\mathrm{AAR}$ of the estimation period for the entire sample and S(AARe) represents the standard deviation of the AAR of the estimation period.

\section{Hypothesis for the study}

$\mathrm{H}_{0}$ : There is no abnormal return on the day of the stock splits announcement.

$\mathrm{H}_{1}$ : There is abnormal return on the day of the stock splits announcement

\section{Findings}

In the pre split event window i.e days from $t$ $=-20$ day to $t=-1$ day, table no. 1 reveals that the Average Abnormal Returns (AAR) are positive except on days $t=-5, t=-4$ and $\mathrm{t}=-1$. The highest return in the pre split event window is on day $\mathrm{t}=-14$ with $1.279 \%$ and the lowest return of $-5.1 \%$ is on day $t=-$ 1. The AAR on days $\mathrm{t}=-20, \mathrm{t}=-17, \mathrm{t}=-16$, $\mathrm{t}=-13$ and $\mathrm{t}=-8$ are statistically significant at 5\% level in the pre split event window. The Cumulative Average Abnormal Returns (CAAR) rises from $1.229 \%$ on day $t=-20$ to $11.79 \%$ on day $t=-6$. The CAAR fluctuates from day $\mathrm{t}=-7$ and decreases to a value of $4.19 \%$ on day $\mathrm{t}=-1$. The AAR on the announcement day, $\mathrm{t}=0$ is $2.029 \%$, the highest for the event window and statistically significant with a $\mathrm{p}$ value of 0.014 at $5 \%$ level of significance. This result is similar to that of Banerjee and Banerjee (2010) in the Indian stock market, who found statistically significant AAR of $0.80 \%$ 
Asia Pacific Journals

on announcement day. It also corresponds to

$1.08 \%$ which was statistically significant.

another study of the Indian stock market by

Joshipura (2008) who arrived at AAR of

Table No. 1: Table showing the AAR and CAAR from -20 day to + 20 day.

\begin{tabular}{|l|l|l|l|l|}
\hline DAY & AAR & t statistic & Sig. (2-tailed) & CAAR \\
\hline $\mathbf{- 2 0}$ & 1.2295 & 2.017 & $.048^{* *}$ & 1.2295 \\
\hline $\mathbf{- 1 9}$ & 0.25197 & 0.195 & .846 & 1.48147 \\
\hline $\mathbf{- 1 8}$ & 0.30107 & 0.902 & .371 & 1.78253 \\
\hline $\mathbf{- 1 7}$ & 0.57499 & 2.059 & $.044^{* *}$ & 2.35752 \\
\hline $\mathbf{- 1 6}$ & 1.09676 & 2.590 & $.012^{* *}$ & 3.45428 \\
\hline $\mathbf{- 1 5}$ & 0.431 & .526 & .601 & 3.88528 \\
\hline $\mathbf{- 1 4}$ & 1.27963 & 1.829 & .073 & 5.16491 \\
\hline $\mathbf{- 1 3}$ & 1.24979 & 3.783 & $.000^{* *}$ & 6.4147 \\
\hline $\mathbf{- 1 2}$ & 0.49231 & .777 & .441 & 6.90702 \\
\hline $\mathbf{- 1 1}$ & 0.61875 & 1.203 & .234 & 7.52577 \\
\hline $\mathbf{- 1 0}$ & 0.30565 & .359 & .721 & 7.83142 \\
\hline $\mathbf{- 9}$ & 0.67247 & .998 & .323 & 8.50389 \\
\hline $\mathbf{- 8}$ & 1.05995 & 2.288 & $.026^{* *}$ & 9.56384 \\
\hline $\mathbf{- 7}$ & 1.48438 & 1.260 & .213 & 11.0482 \\
\hline $\mathbf{- 6}$ & 0.74887 & -.366 & .420 & 11.7970 \\
\hline $\mathbf{- 5}$ & -2.5816 & -.813 & .531 & 9.2154 \\
\hline $\mathbf{4}$ & -1.7623 & -.630 & .104 & 7.45323 \\
\hline $\mathbf{- 3}$ & 0.90203 & 1.653 & .458 & 8.35526 \\
\hline $\mathbf{- 2}$ & 0.94471 & .747 & .198 & 9.29997 \\
\hline $\mathbf{- 1}$ & -5.1005 & -1.304 & .198 & 4.19947 \\
\hline $\mathbf{0}$ & 2.02932 & -2.533 & $.014^{* *}$ & 6.22879 \\
\hline $\mathbf{1}$ & -3.0602 & -.727 & .470 & 3.16856 \\
\hline $\mathbf{2}$ & 1.31838 & 1.927 & .059 & 4.48693 \\
\hline $\mathbf{3}$ & 0.48885 & .394 & .695 & 4.97578 \\
\hline $\mathbf{4}$ & 0.66226 & 1.097 & .277 & 5.63804 \\
\hline $\mathbf{5}$ & 0.7639 & 1.565 & .123 & 6.40194 \\
\hline & & & & \\
\hline
\end{tabular}




\begin{tabular}{|l|l|l|l|l|}
\hline $\mathbf{6}$ & -0.0515 & -.070 & .945 & 6.35045 \\
\hline $\mathbf{7}$ & 0.72741 & .750 & .457 & 7.07786 \\
\hline $\mathbf{8}$ & 1.1771 & 1.153 & .254 & 8.25496 \\
\hline $\mathbf{9}$ & 0.82159 & 1.450 & .153 & 9.07655 \\
\hline $\mathbf{1 0}$ & 0.5856 & 1.367 & .177 & 9.66215 \\
\hline $\mathbf{1 1}$ & 0.98275 & .690 & .493 & 10.6449 \\
\hline $\mathbf{1 2}$ & 0.97213 & 1.858 & .068 & 11.617 \\
\hline $\mathbf{1 3}$ & 1.0398 & 1.723 & .090 & 12.6568 \\
\hline $\mathbf{1 4}$ & 0.25252 & .435 & .666 & 12.9093 \\
\hline $\mathbf{1 5}$ & 0.2682 & .555 & .581 & 13.1775 \\
\hline $\mathbf{1 6}$ & 0.1902 & .145 & .886 & 13.3678 \\
\hline $\mathbf{1 7}$ & 0.54472 & .722 & .473 & 13.9125 \\
\hline $\mathbf{1 8}$ & 0.53967 & 1.116 & .269 & 14.4521 \\
\hline $\mathbf{1 9}$ & 1.00321 & 1.945 & .057 & 15.4554 \\
\hline $\mathbf{2 0}$ & 0.90029 & 1.759 & .084 & 16.3556 \\
\hline
\end{tabular}

**indicates significance at 5\% level.

Analyzing the post split event window, it is interesting to note that lowest AAR of $3.0602 \%$ and the highest AAR of $1.3183 \%$ falls on consecutive days i.e days $t=+1$ and $\mathrm{t}=+2$. The AARs in the post split event window are positive except for days $t=+1$ and $\mathrm{t}=+6$. There is a gradual rise in CAAR from $3.168 \%$ on day $\mathrm{t}=+1$ to day $\mathrm{t}=+20$. The study also analyses the short term window i.e days $t=+1$ to $t=-1$ around the announcement day. The results reveal that the day prior to and after the announcement day, the AARs show high negative values of $-5.1005 \%$ for day $\mathrm{t}=-1$ and $-3.0602 \%$ for day $\mathrm{t}=+1$. These returns are also the lowest in the entire window period of 41 days. These results are in contrary to Banerjeee and Banerjee (2010) whose results showed positive AARs for day $\mathrm{t}=-1$ and day $\mathrm{t}=+1$.
It can also be observed from the study that 37 companies AAR show positive returns while remaining 19 companies exhibit negative AARs on the announcement day. The results in table no. 1 show that $\mathrm{p}$ value (0.014) is less than 0.05 on the announcement day at $5 \%$ level of significance. The study rejects the null hypothesis and concludes that there are abnormal returns on the day of the stock split announcement.

\section{Conclusion}

Proposed by Fama (1970) the Efficient market Hypothesis (EMH) is a groundbreaking theory of the securities market. Fama categories efficiency of markets into weak form, semi strong form and the strong form. The current study tests the semi strong form of the EMH in the Indian context. The 
ELK

Asia Pacific Journals

effect of Stock splits announcements is studied for companies listed in the National Stock Exchange for the period 2009 to 2013. The study observes that average abnormal return on the day of announcement for the sample is $2.029 \%$ which is statistically significant at 5\% level. Moreover, 37 out of 56 sample companies show positive abnormal average return on the announcement day of the split. Applying hypothesis testing, the study concludes that there are abnormal returns on the day of the stock split announcement.

\section{References}

[1] Aduda, J. O. (2010). Market Reaction to Stock Splits: Empirical Evidence from Nairobi Stock Exchange. African Journal of Business and Management, 1, 165-184.

[2] Asquith, P., Healy, P., \& Palepu, K. (1989). Earnings and Stock Splits. The Accounting Review, 64 (3), 387-403.

[3] Baker, H. K., \& Gallagher, P. L. (1980). Management's view of Stock-Splits. Financial Management, 9, 73-79.

[4] Banerjee, P., \& Banerjee, P. S. (2010). The Information Content and Stock Return Behavior around the Stock Splits - Evidence from India. Paradigm, 14 (2),

www.freepatentsonline.com/article/Para digm/297309484.html.

[5] Barber, B., \& Lyon, J. (1997). Detecting long-run abnormal stock returns: the empirical power and specifications of
ELK Asia Pacific Journals - Special Issue ISBN: 978-81-930411-5-4

test statistics, . Journal of Financial Economics , 43, 341-372.

[6] Brennan, M. J., \& Copeland, T. E. (1988). Stock-Splits, Stock-Prices and Transaction Costs. Journal of Financial Economics , 22, 83-101.

[7] Byun, J., \& Rozeff, M. (2003). LongRun Performance After Stock-Splits: 1927 to 1996. The Journal of Finance, 5 (3), 1063-1085.

[8] Conroy, R. M., Harris, R. S., \& Benet, B. A. (1990). The Effects of Stock Splits on bid-ask Spreads. Journal of Finance , 45, 1285-1295.

[9] Desai, H., \& Jain, P. (1997). Long-run common stock returns following stock splits and reverse splits. Journal of Business , 70, 409-433.

[10] Fama, E., Fisher, L., Jensen, M., \& Roll, R. (1969). The Adjustment of Stock Prices to New Information. International Economic Review , 10, 121.

[11] Grinblatt, M. S., Masulis, R. W., \& Titman, S. (1984). The Valuation Effects of Stock Splits and Stock Dividends. Journal of Financial Economics , 13 (4), 461-490.

[12] Gupta, A., \& Gupta, O. P. (2007). Market Reaction to Stock Market Splits: Evidence from India. The Icfai Journal of Applied Finance , 13 (1), 5-22.

[13] Ikenberry, D. L., Rankine, G., \& Stice, E. (1996). What Do Stock Splits Really Signal ? Journal of Financial and Quantitative Analysis , 31, 357-375.

[14] Joshipura, M. (2008). Price and liquidity effects of stock split:An 
Empirical evidence from Indian stock market. NSE India , 2-20.

[15] Lakonishok, J., \& Lev, B. (1987). Stock Splits and Stock Dividends: Why, Who and When. The Journal of Finance , 42, 913-932.

[16] Lamoureaux, C. G., \& Poon, P. (1987). The Market Reaction to Stock Splits. Journal of Finance , 42, 13471370.

[17] Maloney, M. T., \& Mulherin, J. H. (1992). The Effects of the Splitting on the Ex: A MicroStructure Reconciliation. Financial Management, 21, 44-59.

[18] McNichols, M., \& Dravid, A. (1990). Stock Dividends, Stock Splits, and Signaling. The Journal of Finance, 45 (3), 857-879.

[19] Musau, M. (2007, March 14). Stock Splits: The Hidden Flaws. The African Executive , p. www.africanexecutives.com/modules/m agazines/articles.

[20] Pilotte, E., \& Manuel, T. (1996). The Market's Response to Recurring Events: The Case of Stock Splits. Journal of Financial Economics , 41, 111-127.

[21] Shirur, S. (2008). Dilemma of Corporate Action: Empirical Evidences of Bonus Issue vs. Stock Split. Vikalpa, 33 (3), 35-47.

[22] Thirunellai, S. (2013). Stock Splits: Reasons and Valuation Effects. NSE India Publications , 1-24. 